\title{
On Macroeconomic Reforms and Macroeconomic Resiliency: Lessons from the Great Recession
}

\author{
Peter J. Montiel \\ Department of Economics, Williams College, Williamstown, USA \\ E-mail:pmontiel@williams.edu \\ Received March 30, 2011; revised May 20, 2011; accepted May 29, 2011
}

\begin{abstract}
What are the payoffs from macroeconomic reforms? Whether such reforms yield higher long-term growth has long been controversial. However, the experience of the Great Recession suggests that other important benefits may have been neglected in the controversy over the growth benefits of reform. Specifically, in contrast with previous international recessions, recovery from the Great Recession has been led by emerging and developing economies, many of which have implemented significant reforms over the past two decades. How much of the resilience of these economies can be attributed to these reforms, and what do these lessons suggest for the desirability of further reforms? This paper is intended to provide some preliminary answers to these questions.
\end{abstract}

Keywords: Great Recession, Macroeconomic Reform, Countercyclical Policies

\section{Introduction}

The last two decades have been a period of intensive macroeconomic reform in emerging and developing economies. These reforms have proven immensely controversial. Some critics have argued that their content was too narrow, ${ }^{1}$ while others have argued that it was too broad. ${ }^{2}$ The debate over reform strategies has taken for granted that the objective of reforms is to stimulate growth. Consequently, criticism of orthodox reform has often centered on the dual observations that countries that have grown rapidly in the past have not always adopted orthodox reform prescriptions, and countries that have adopted orthodox reform prescriptions have often not grown very rapidly. ${ }^{3}$

While such a perspective is not inappropriate in the sense that the objective of reform is ultimately to improve living standards, this may be to take too narrow a view of the potential benefits of reform. Economic wel-

\footnotetext{
${ }^{1}$ Stiglitz [1] argued that the strategy embodied in the Consensus needed "broader goals and more instruments." Specifically, he claimed that it neglected government effectiveness, transparency, sound financial regulation, competition policy, and policies for technology transfer. ${ }^{2}$ The "growth diagnostics" strategy of Hausmann, Rodrik, and Velasco [2], for example, is based on identifying the binding constraints on growth, rather than adopting a multitude of reforms in the hope of kick-starting growth.

${ }^{3}$ On the former, see [3]. On the latter, see [4-7].
}

fare depends not just on the level of income that a country achieves, but also on the stability of that income. Moreover, income stability may matter not just for its own sake, but also for its eventual positive effect on economic growth. Thus, reforms that enhance income stability may improve economic welfare both directly and indirectly. Yet the role of economic reforms in promoting income stability has received little attention to date.

The Great Recession of 2007-2010 provides an opportunity to take stock of the extent to which the macroeconomic reforms of the last two decades have indeed helped to promote macroeconomic stability among emerging and developing economies by helping those economies become more resilient in the face of shocks. The fact that this recession has been unique among recent recessions in that international recovery has actually been led by emerging and developing economies is suggestive. The key question, however, concerns the extent to which this growth resilience among emerging and developing economies can be attributed to the macroeconomic reforms that these countries implemented prior to the outbreak of the recession in 2007.

This paper examines this question. The next section examines what we know about why growth has proven to be so much more volatile in emerging and developing countries than in high-income countries. Its purpose is to 
investigate whether the sources of high volatility in such countries are likely to be such that they can indeed be addressed through the types of reforms that these economies have recently implemented. Section 3 then documents the content of reform in the two decades or so leading up to the Great Recession. This sets the stage for an examination of experience with the Great Recession itself. The effects of the recession on the macroeconomic environment facing emerging and developing economies -in other words, the channels of transmission of the recession to those economies-is the subject of Section 4. This is followed by an examination of these countries' macroeconomic policy responses in Section 5. Section 6 then examines the post-crisis performance of those economies and links it to the reforms that they previously undertook. The final section summarizes and concludes.

\section{Growth Volatility in Developing Countries}

Explanations for macroeconomic volatility tend to be of two types. Researchers who have examined cross-country differences in volatility have tended to emphasize structural factors. The roles of such factors can be interpreted as determining a country's susceptibility to shocks as well as its fragility in response to such shocks. A different strand of literature, typically focused on individual-country experiences (e.g., case studies), has emphasized the roles of domestic macroeconomic policy regimes, especially concerning fiscal policy (degree of procyclicality), monetary policy (Central bank independence and the monetary policy regime) and exchange rate policies (e.g., fixed versus floating, the performance of "hard" exchange rate pegs).

Of course, these perspectives are not mutually exclusive. A common-sense interpretation of the sources of volatility would view observed volatility as the outcome of a complex interaction among the frequency and severity of shocks and the fragility of the domestic economy in the face of such shocks in the absence of a policy response, on the one hand, and the effectiveness of domestic policy responses, on the other. Indeed, it is possible to read much of the evidence on the determinants of volatility in exactly this way.

That evidence suggests that sustained growth accelerations tend to be associated with financial and macroeconomic reforms, and that episodes of negative growth rates are associated with financial and macroeconomic shocks (see, e.g., [8]). The question, then, is what accounts for such shocks?

Financial and macroeconomic shocks could emerge in two ways: they could represent shocks triggered by inappropriate domestic financial and macroeconomic policies, or they could emerge from poor macroeconomic responses to exogenous shocks. There is evidence that both have been important in emerging and developing countries, and that the policies implicated have run the full macroeconomic gamut of fiscal, monetary, exchange rate, and financial-sector policies.

An important source of macroeconomic shocks in such countries has been actual or prospective fiscal insolvency, in the form of unsustainable debt levels. Debt defaults have been quite common among emerging and developing economies, and [9] have estimated that defaults have been associated with growth shortfalls of about 2 percent per year on average over a two-year horizon and 0.8 percent on average on average over a six-year horizon. Moreover, high levels of debt and prospective insolvency have been associated with procyclical fiscal policies, (see [10]).

Shortcomings in monetary policy have played a similar role. Just as have debt defaults, episodes of sustained high inflation and brief hyperinflation have historically been quite common among emerging and developing economies, resulting in growth volatility associated both with the period of high inflation itself as well as with its eventual stabilization. These episodes have often been associated with the monetization of fiscal deficits, as the result of de jure or de facto fiscal dominance. A history of high inflation has also served to paralyze monetary policy as a stabilization instrument, because the fear that monetary expansion would trigger self-fulfilling inflationary expectations has often prevented Central banks in emerging and developing economies from lowering interest rates in response to recessions. Indeed, a perceived need to convince markets that monetary financing would not be forthcoming for fiscal deficits caused by recession has often caused monetary tightening - and thus procyclicality-in countries with an inflationary history.

The absence of monetary credibility has caused many emerging and developing economies to rely on the exchange rate as a nominal anchor. Consequently, fixed exchange rate regimes have been much more common among emerging and developing economies than among high-income countries [11]. This has had two implications for growth volatility. First, "soft" exchange rate pegs have proven vulnerable to currency crises, with associated negative effects on growth rates. Second, the unwillingness to countenance exchange rate flexibility has prevented the use of the exchange rate as a tool of stabilization policy. Indeed, defending the exchange rate in the face of capital outflows has been an important factor in rendering monetary policy procyclical, as in immediate post-crisis Asia.

Finally, inappropriate liberalization of the domestic financial sector-liberalization without the appropriate regulatory and supervisory safeguards in place-has also aggravated boom and bust cycles in emerging and developing economies. Poor regulation and supervision of a liberalized financial sector has in many cases facilitated 
the emergence of currency mismatches and of credit booms and asset price bubbles, and the resulting vulnerability of banks' balance sheets has not only tended to magnify the effects of exogenous shocks by coupling them with a banking crisis, but has also helped to paralyze monetary policy for fear of adverse effects on banks' balance sheets.

\section{What Has Been Reformed}

Reference [12] argues that variables in growth regressions tend to have significant effects because they are symptoms of one of three syndromes that are harmful for growth: state-led development with a non-developmental state, excessive inward orientation, and chronic or severe episodes of macroeconomic imbalance or instability. These findings provide the rationale for the orthodox reform prescription of "privatize, liberalize, stabilize." But it is worth noting that reforms of these types need not necessarily be stabilizing. In particular, to the extent that the "liberalize" component involves enhanced real and financial openness, the effects on macroeconomic stability are ambiguous, since reforms of this type increase the economy's exposure to external shocks while simultaneously altering its response to domestic shocks in ways that may be either stabilizing or destabilizing. Moreover, "second generation" reforms, especially those directed at the domestic financial sector, may also prove to be either stabilizing or destabilizing, depending on how they are implemented.

One would think that the "stabilize" component of the Consensus would be stabilizing-by definition! But that is not necessarily the case. The key issue here is a tradeoff between credibility and flexibility. Reforms that seek to ensure that domestic macroeconomic policies do not themselves become a source of shocks-and thus emphasize the credibility of the domestic macroeconomic policy framework-may create rigidities that simultaneously make the economy more vulnerable to exogenous shocks and less capable of compensating for those shocks by undertaking stabilizing policy responses. The key point, then, is that what matters for stability is not reform per se, but rather what has been reformed, and how.

In this respect, the news is relatively good for emerging and developing economies: while the reforms of the 1990s and 2000s may have left these countries more exposed to external shocks, the content of those reforms would have led one to expect ex ante much more resiliency in the face of such shocks.

Trade liberalization (the replacement of QRs with tariffs, movements to uniform tariffs, and tariff reductions), has been ongoing among emerging and developing economies over the past two decades. This has had the effect of making these countries increasingly integrated with the world economy. Capital account liberalization undertaken by many emerging and developing economies after 2000 also caused them to become more integrated with the rest of the world financially.

As would be expected, increased openness and the resulting increased integration with world markets has indeed made emerging and developing countries more vulnerable to external shocks, both financial and real. Reference [13], for example, estimates that external factors account for more than half of the medium-term variance of Latin American growth, with external financial conditions accounting for about 35 percent, foreign growth for 10 - 15 percent, and commodity price fluctuations for 5 - 6 percent.

Other reforms, however, have clearly been vulnerability-reducing. A key source of macroeconomic vulnerability, for example, is the health of the financial system. As the result of financial reforms undertaken over the past decade and a half, including improvements in financial regulation and supervision, enhanced competition in the financial system, and in some cases the recent resolution of banking crises, the financial systems of many emerging and developing economies are healthier today than they have been in the past. The entry of foreign banks has also significantly contributed to the health of domestic financial systems, especially in Latin America and sub-Saharan Africa. ${ }^{4}$

The key development in the area of exchange rate management is that many emerging and developing economies, especially in Asia and Latin America, have transitioned to more flexible exchange rate arrangements, reducing vulnerability to the disruptive discrete exchange rate depreciations that are associated with currency crises, and providing an automatic stabilizing effect in response to external financial shocks. Moreover, despite still being pronounced in some countries, financial dollarization has declined, reducing the impact of a factor that has weakened or even reversed the otherwise expansionary effect of exchange rate depreciation in the past. ${ }^{5}$

However, these regimes remained heavily managed, as Central banks in many emerging and developing economies engaged in heavy sterilized intervention to avoid

${ }^{4}$ However, the situation was rather different before the outbreak of the Great Recession in the transition economies of Central and Eastern Europe. Banking sectors were liberalized there after transition in the early $1990 \mathrm{~s}$. However, the institutional infrastructure for the financial sector remains deficient in many countries, and in particular, the local subsidiaries of foreign banks have not always been well capitalized. Many banks in the region relied heavily on nondeposit funding, especially from parent banks in Western Europe. Moreover, while their domestic loans were generally denominated in foreign currency, they tended to be extended to unhedged domestic borrowers, supporting activities in the nontraded goods sector such as real estate investments. ${ }^{5}$ To the extent that currency mismatches are induced by fixed exchange rate regimes combined with lax financial regulation, improved regulation and more flexible exchange rate management could be behind the reduction in the extent of such mismatches in Latin America. 
real exchange rate appreciation. ${ }^{6}$ Heavy Central bank intervention in foreign exchange markets resulted in many of these economies building up truly massive stocks of foreign exchange reserves by 2007, as shown in Figure 1.

Although the move to floating rates was less pronounced outside of emerging Asia and Latin America, reserve accumulation was a common feature. In the Middle East and Central Asia, for example, both countries with fixed regimes as well as those with managed floats accumulated large stocks of foreign exchange reserves prior to $2007 .^{7}$

In the area of monetary policy, the key development in many emerging and developing economies is that Central banks have been substantially strengthened as macroeconomic institutions. Not only have they been accorded legal independence, but they have taken responsibility for maintaining low and stable inflation rates - often by adopting formal inflation targeting - and to a significant extent they have achieved that goal in recent years, enhancing their credibility.

Reforms in the fiscal area have encompassed both fiscal institutions and fiscal policy regimes. The reform of fiscal institutions has typically taken the form of the enactment of fiscal responsibility laws of various types. In some cases reforms in expenditure processes, improvements in tax administration, and reforms of the tax structure have enhanced the flexibility of fiscal systems

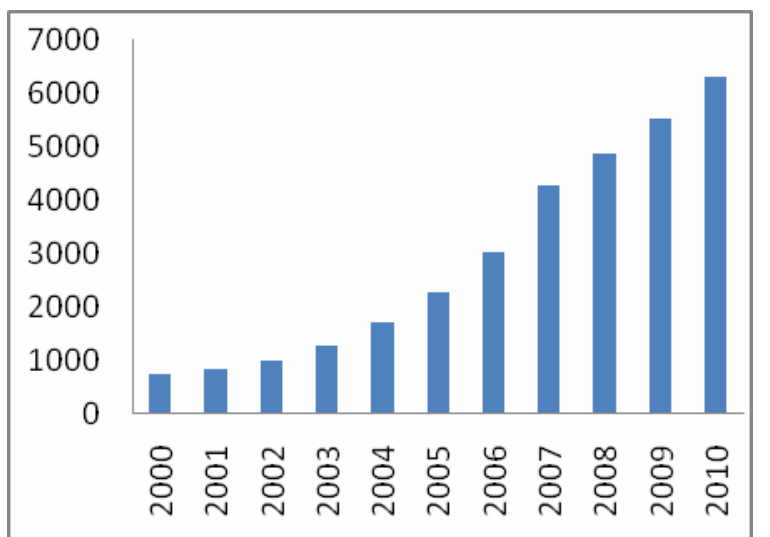

Figure 1. International Reserves, Emerging and Developing Countries, 2000-2010 (US \$ billions); Source: IMF, International Financial Statistics.

\footnotetext{
${ }^{6}$ For the evolution of exchange rate regimes in post-crisis Asia, see [14].

${ }^{7}$ The transition economies of Central and Eastern Europe were once again somewhat different. In seeking to integrate with Western Europe, many of the countries in emerging Europe maintained fixed exchange rates. While these countries also received large capital inflows in the pre-crisis period, those inflows were just enough to finance large current account deficits. Therefore, unlike emerging and developing economies elsewhere, those in emerging Europe entered the Great Recession with low ratios of reserves to short-term external debt.
}

and strengthened the effects of automatic fiscal stabilizers. But the most important changes in fiscal policy regimes have involved the demonstration in many countries of both the political will as well as the economic ability to make significant fiscal adjustments-especially to exercise fiscal restraint during good times. This has been an important break from the procyclical fiscal behavior of the past. These reforms and changes in fiscal policy regimes have enhanced fiscal credibility, as evidenced in many cases by reductions in sovereign risk premia. One important consequence of these changes in fiscal performance is that public debt stocks as a proportion of GDP have declined in many emerging and developing countries over the past several years. ${ }^{8}$

In short, emerging and developing economies became increasingly integrated with the world economy during the past two decades, along both real and financial dimensions. While this has increased their exposure to external shocks, a better composition of external financing, stronger domestic financial systems with improved corporate governance, better monetary policy frameworks, strong fiscal positions, more flexible exchange rate regimes, and large reserve accumulation have all reduced vulnerability and placed these economies in a more favorable position to respond to such shocks with expansionary policies. All of these factors suggest that the large external shock that the Great Recession represented for emerging and developing economies would be less disruptive than the history of these economies would otherwise have led one to believe. Most important, perhaps, is that reforms to domestic financial systems and moves to more flexible exchange rate regimes rendered the sudden disruptions associated with "twin" banking and currency crises less likely, that the credibility gained by financial and macroeconomic policy institutions would make short-run deviations from medium-term policy stances less disruptive to expectations, and that policymakers entered the crisis with means at their disposal to counter shocks - in the form of large reserve stocks - that were not available to them in the past.

\section{Crisis Transmission and Impact}

The Great Recession began with a collapse in housing prices in the United States, which triggered a financial panic because of the opaque nature of securitized mortgage instruments, which quickly became "toxic assets." The financial panic was followed by a collapse of real activity as the result of reduced asset values and the freezing up of credit flows. An initial channel of international transmission was financial, and primarily affected

${ }^{8}$ Pre-crisis public sector balance sheets were relatively strong even in emerging Europe, in the sense that public sector debt/GDP ratios tended to be lower than those in other emerging-economy regions. 
Western European countries whose private capital markets are tightly integrated with those of the United States, and whose financial institutions had acquired toxic assets issued in the United States. However, financial institutions in emerging and developing countries did not typically acquire such assets, so they did not experience the direct hit suffered by similar institutions in many industrial countries.

A second financial link was less direct, but had more worldwide effect. As the crisis deepened in the advanced economies, all projections for the world economy became more uncertain. This increase in worldwide economic and political uncertainty acted like a "monsoon effect" that sharply reduced productive asset values throughout the world. Stock markets around the world moved in sympathy, and the crisis spread through a worldwide decline in equity prices, affecting more directly emerging and developing economies with more highly developed stock markets.

A third financial channel of transmission operated through a reallocation of international financial portfolios from risky assets to those assets perceived as safest: United States government obligations and gold. This had two important implications. First, it increased sovereign borrowing costs for emerging and developing countries. Second, countries with currencies closely tied to the U.S. dollar faced an additional negative shock in the form of real effective exchange rate appreciation, pulled along by the appreciation of the dollar, while those with floating rates faced pressure for their currencies to depreciate as capital flowed out of their economies. Whether this resulted in an additional negative effect on aggregate demand in these countries or a positive one depended on their domestic vulnerability to exchange rate depreciation.

The fourth channel of transmission arose from a dramatic contraction in economic activity in the North Atlantic economies. This manifested itself in three "real" channels of transmission: a decline in the demand for the exports of developing countries, a reduction in commodity prices, and a sharp contraction in flows of worker remittances.

The crisis had differential effects on emerging and developing economies, depending on the nature of their links with the international economy. The initial impact of the crisis on Asian and Latin American economies was financial. Stock markets peaked in many such countries in October of 2007, and by February 2009, they had fallen by 60 percent. Net portfolio equity inflows and bank lending flows collapsed, and access to external bond financing became much harder. Increased "real" integration subsequently caused the crisis to be transmitted to both regions through markets for goods and ser- vices. Exports to the United States and the European Union from emerging Asia fell sharply in 2007, and emerging economies in Asia suffered some of the sharpest contractions in real output experienced anywhere, including in the industrial countries where the crisis originated. Real GDP in emerging Asia excluding China and India contracted by 15 percent on an annualized basis in the fourth quarter of 2008, for example, compared to six percent in the United States. Finally, countries in Latin America, especially Mexico and countries in Central America, suffered a sharp contraction in flows of workers' remittances.

In the Middle East and Central Asia, the collapse in oil prices caused by the reduced level of economic activity in oil-importing countries played an important role in crisis transmission. As in other regions, stock markets contracted and spreads for banks that borrowed heavily from abroad widened. Similar to elsewhere, countries in the Middle East and Central Asia also suffered a decline in FDI flows, reduced demand for the region's exports, lower tourism receipts, and a sharp reduction in flows of worker remittances. Because many countries in this region were pegged to the US dollar, the 'safe haven' appreciation of the dollar resulted in a real effective appreciation of their currencies, adding an additional contractionary shock.

The most important financial channel of transmission for most countries in sub-Saharan Africa was reduced FDI inflows. As in other regions, real transmission occurred through reduced demand for exports, lower commodity prices, and reduced flows of remittances.

Countries in emerging Europe are highly integrated with Western Europe, in both real and financial markets, and they rely much more on external bank financing than do other emerging economies. As in Asia and Latin America, the crisis hit early. Sovereign risk premia began to turn up in mid-2007, and increased continuously thereafter. Private external bond issues also contracted sharply in mid-2007, and stock prices turned down at the same time. The sharp contraction in foreign bank credit to these countries caused the collapse of a real estate boom that had emerged in the Baltic economies prior to 2007, which contributed to dramatic contractions in economic activity in these countries, similar to those observed in Asia and in countries, such as Mexico, that were tightly integrated with advanced economies at the epicenter of the crisis.

The upshot is that emerging and developing economies had not "decoupled" at the outset of the Great Recession. Far from it, the macroeconomic reforms that they had implemented in the decade and a half or so prior to the crisis-particularly the "liberalizing" reforms that can caused them to open their current and capital ac- 
counts, and therefore to greatly increase their real and financial integration with the advanced economies-if anything made them more susceptible to the crisis in the advanced economies, through a diverse set of transmission channels. Moreover, the reform and development of their domestic financial sectors, by strengthening crossborder banking links and giving a more prominent role to stock markets in the domestic economy, may independently have strengthened financial channels of transmission. Not surprisingly, then, emerging and developing economies all over the world suffered severe initial output contractions, in many cases much more severe than those that afflicted the countries at the epicenter of the crisis.

\section{Policy Response}

Based on past experience, the effect of such severe output contractions in emerging and developing economies would have been expected to have been a prolonged period of stagnation, perhaps another "lost decade," such as the one that Latin America suffered through after the 1982 debt crisis. Dislocations in domestic financial systems, the drying up of capital inflows as a result of a loss of confidence by international investors, and procyclical fiscal policies focused on reductions in public sector investment, driven by revenue shortfalls and the absence of means to finance deficits other than by printing money, would all have contributed to such an outcome. Such destructive policies would have been abetted by high inflation if the difficulty of financing fiscal deficits caused the affected countries to turn on the monetary spigot (as after the 1982 Latin American crisis), or by its opposite-very tight monetary policies-if worries about currency mismatches in domestic balance sheets constrained monetary expansion (as after the 1997 Asian crisis). Such outcomes would have been expected to have been even more likely if recovery were slow in the advanced economies, as was indeed the case.

In the event, in the majority of emerging economies as well as many developing countries, none of this happened. Countries that had undertaken significant macroeconomic reforms prior to the crisis instead responded to the severe external shock that the Great Recession represented for them by adopting countercyclical policies - in some cases very aggressive ones.

The resiliency of reformed financial sectors in emerging economies, and lessons learned from the past about how to safeguard these systems, provided an important buffer for these economies. Asian credit markets, for example, were not disrupted in 2007, when these countries' exports collapsed. Although confidence in some Asian banks suffered after the collapse of Lehman Brothers in September of 2008, several governments quickly created liquidity facilities and expanded deposit insurance. As a result, credit did not freeze up in Asia, as it did temporarily in the United States and Western Europe. A similar situation prevailed in Latin America.

Floating exchange rates also contributed to stabilizing aggregate demand in most (but not all) emerging economies. The "safe haven" effect that saw capital flow from all over the world into US Treasury bills put pressure on the exchange rates of emerging economies with floating rates to depreciate. Most such economies did not resist depreciation, though several accepted some reserve losses in order to smooth their exchange rate changes. The experience of the seven largest Latin American economies (the LAC-7) is shown in Figure 2. ${ }^{9}$

Low inflation and monetary credibility made it possible for a large number of both emerging and developing economies, both with floating as well as officially-determined exchange rates, to respond to the crisis with monetary easing without fear of igniting inflation expectations. Monetary conditions began to be eased in Asia the spring of 2007, when the recession began to affect Asian exports, and easing became more aggressive in the last quarter of 2008, after the collapse of Lehman Brothers. The median decline in policy rates in the region from the 3rd quarter of 2008 to the 2nd quarter of 2009 exceeded $21 / 4$ percent, five times as much as in past recessions [15]. Monetary policy turned expansionary in Latin America somewhat later than in Asia, but as in Asia became even more expansionary in late 2008. Policy rates were lowered in all the major inflation-targeting emerging economies in the region, as well as in non-inflation targeting countries such as the Dominican Republic, Honduras, Paraguay, and Venezuela [16]. In sub-Saharan Africa, two-thirds of the countries lowered one or more

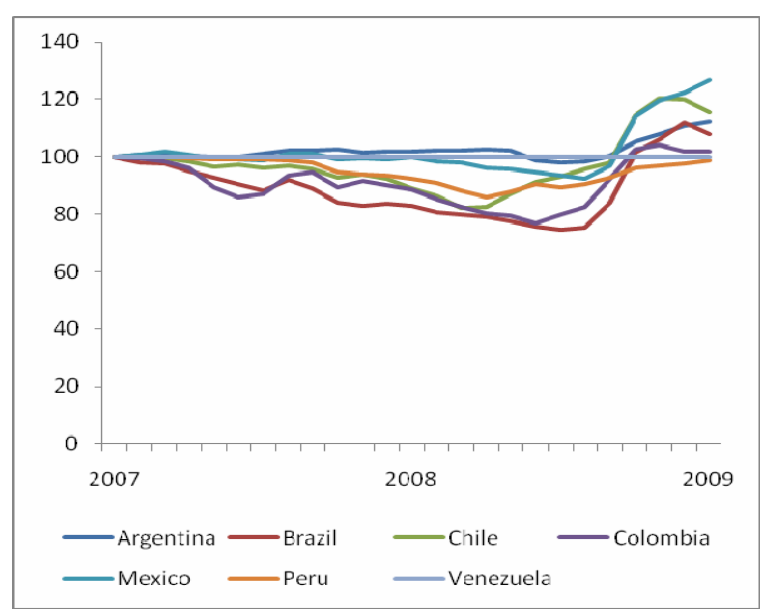

Figure 2. Bilateral US \$ Exchange Rates, LAC-7, 2007:1 to 2009:1 (2007:1 = 100); Source: IMF, International Financial Statistics

${ }^{9} \mathrm{~A}$ decrease in the exchange rate index in the figure is an appreciation. 
policy interest rates after the crisis began.

Modest debt levels and large stocks of foreign exchange reserves created the "fiscal space" for many emerging economies to implement fiscal expansions without fear of perceived threats to fiscal solvency. The IMF's calculations show a positive fiscal stimulus in China, India, the four tigers, and the ASEAN-4 economies (Indonesia, Malaysia, the Philippines, and Thailand) during 2009 that were comparable or larger in size than those on the G-20 countries on average (2 3/4 percent of GDP, compared to about 2 percent in the G-20 countries). ${ }^{10}$ Throughout the region discretionary fiscal measures were heavily weighted toward spending, especially investment in infrastructure, and were implemented quickly. The Fund found the fiscal policy response to the current recession in Asia to be stronger than in past recessions, with a median increase in the fiscal deficit of over $3 \frac{1}{2}$ percent, more than double the response after the Asian crisis. Aggressive fiscal policy responses were also implemented in Latin America, though those packages were more modest than those in Asia. The fiscal authorities in Brazil, Chile, Colombia, Mexico and Peru provided the most support, increasing their average domestic primary deficit by some 3.5 percent of GDP in 2009. This reflected not just automatic stabilizers, but also discretionary measures, since the cyclically-adjusted primary balance was loosened in those countries, resulting in positive fiscal impulses. ${ }^{11}$ Fiscal policy was eased in some three quarters of sub-Saharan African countries in response to the Great Recession [18]. Fiscal deficits increased as the result of automatic stabilizers as well as discretionary responses. The IMF notes that nearly two-thirds of the Sub-Saharan African countries that experienced growth slowdowns as a result of the crisis were actually able to increase government spending to stabilize their economies [19]. The turnaround in fiscal balances amounted to some 6 percent of GDP on average in 2008, a sharp contrast with experience during past recessions. In the Middle East and Central Asia, countries with substantial fiscal cushions undertook substantial fiscal stimulus programs, as in Asia and Latin America. Where they were present, sovereign wealth funds responded to the contraction in capital inflows associated with the crisis by lending more actively in their domestic

\footnotetext{
${ }^{10}$ See [15]. China announced a large fiscal stimulus package in November of 2007 focused on a massive program of public investment. The four "tiger" economies of Hong Kong, Korea, Singapore and Taiwan allowed an increase in their fiscal deficits by $2 \frac{1 / 4}{4}$ percent of GDP in 2008.

${ }^{11}$ Reference [17] using a different indicator of fiscal stimulus (the compounded annual growth rate of real exhaustive government spending) found that among the OECD economies, three of the five countries that implemented the largest fiscal stimulus in response to the Great Recession were emerging economies (Chile, Korea, and Mexico) These three countries were also found to have pursued countercyclical fiscal policies in the period before the Great Recession.
}

economies and funding public sector projects. Fiscal stimulus was also widely undertaken by countries in the Caucasus and Central Asia, especially in countries such as Azerbaijan, Turkmenistan and Uzbekistan, which had saved during the boom. This international experience reflects the gradual easing of constraints on countercyclical fiscal response in the form of high debt, high inflation, and large fiscal deficits during boom times.

However, this experience was not uniformly shared among developing countries. Problems in the financial sectors of emerging Europe resulted in credit collapses and contributed to severe output contractions there. In addition to recapitalizing banks, all of the emerging economies in Europe had to substantially increase deposit guarantees, many of those countries negotiated adjustment programs with the International Monetary Fund, in exchange for exceptional financing. ${ }^{12}$ Outside Europe, Kazhakstan had a major banking crisis that was reminiscent of crises in Asia, Mexico, and Chile in previous decades.

Despite capital outflows, exchange rate depreciation was also not universal. Most European emerging economies kept their exchange rates stable against the euro, and since their trade was dominated by Eurozone countries, real effective exchange rate depreciation did not make a significant contribution to shoring up demand. The same was true, of course, for countries in sub-Saharan Africa, such as those in the CFA zone, that maintain fixed rates against the euro. Dollarized economies in Latin America, such as Ecuador and El Salvador, and many countries in the Middle East, both oil exporters and importers, that maintain fixed or heavily managed exchange rates against the US dollar, saw their nominal effective exchange rates appreciate, following the appreciation of the dollar. On the other hand, countries in the Caucasus and Central Asia with more flexible exchange rate regimes were constrained on the extent to which they could allow their currencies to depreciate by an old problem: currency mismatches in the balance sheets of their banks and corporations.

Several emerging and a larger group of developing countries Asia were not in a position to mount a forceful policy response to the crisis. Fiscal policy was actually tightened on average among the group of countries that the IMF classifies as "other" commodity exporters in Latin America (Argentina, Bolivia, Ecuador, Paraguay, Suriname, Trinidad and Tobago, and Venezuela,) resulting in negative fiscal impulses, and thus pro-cyclical fiscal policy. Similarly, tourism-intensive commodity importing countries, the IMF's term for a variety of

\footnotetext{
${ }^{12}$ As of April 14, 2009, IMF programs were in place in Belarus, Bosnia-Herzegovina, Hungary, Latvia, Romania, Serbia, and Ukraine, and Poland availed itself of the IMF's unconditional new Financial Credit Line.
} 
small economies in the Caribbean, tended to have large stocks of public debt on average, and maintained fixed exchange rates in the context of open capital accounts with a fairly high degree of financial integration. These countries consequently had little scope for either fiscal or monetary stimulus. Most low-income economies in Asia found themselves in similar fiscal straits. Those countries were hit by lower commodity prices, reduced demand for nontraditional exports such as garments, lower tourism receipts, and reduced FDI flows. However, weak public solvency positions, reduced fiscal revenues because of lower commodity prices and lower revenue from import taxes, ineffective monetary transmission mechanisms, and inflexible exchange rates rendered countercyclical responses much more difficult to implement in those countries. A similar situation played out in the Middle East. Many countries in that region simply had no fiscal cushions. This was true of oil exporters such as Iran, Sudan, and Yemen, which had to reduce their fiscal deficits in the face of the crisis in order to preserve fiscal sustainability. It was also true on average of the oil-importing countries in the region, which averaged public sector debt to GDP ratios of over 60 percent. Indeed, according to [20], among Middle Eastern oil importing countries, all but Morocco and Tunisia adopted pro-cyclical policies in response to the crisis, tightening fiscal policy to preserve fiscal sustainability in the face of declining revenues.

\section{Post-Crisis Performance}

The pattern of economic recovery among emerging and developing countries followed closely that of the policy response. The heavily export-dependent economies in the Asian region suffered the sharpest output contractions as the result of the crisis, but also the most determined policy response and the fastest recoveries. While the initiation of recovery in Asia during the first quarter of 2009, was led by exports (as the result of an inventory cycle in the United States and the European Union), it was also supported by expansionary domestic policies. Simulations with the IMF's Global Integrated Monetary and Fiscal model (GIMF) reported in [21] estimate that fiscal stimulus in those countries added $13 / 4$ percent on average to growth in Asia during the first half of 2009 . The region benefited in particular from an increase in regional exports to China, responding to the boost given to Chinese demand by the infrastructure investment associated with Chinese fiscal stimulus, as well as to increased private investment in that country caused by the countercyclical relaxation of credit restrictions. These measures, together with the recovery in world trade, had the effect that by August of 2009, alone among the major economies of the world China was growing at rates above its long-run trend. Foreign capital began to flow into Asian countries once again in the second quarter of 2009, and inflows of portfolio equity capital contributed to a sharp rebound in regional stock markets, which soon returned close to pre-crisis levels. Already in 2009, the combination of sustained current account surpluses and restored capital inflows caused Asian economies to begin to accumulate foreign exchange reserves once again.

Latin America also sustained a strong recovery in 2009. It was driven by a combination of expansionary domestic policies, the recovery in world demand for manufactured goods mentioned above, and improved commodity prices, in turn driven by the rapid recovery in the commodity-intensive Asian economies. Both of these components of the external environment began to recover in 2009, though other components, such as remittances and tourism, did not. This meant that the large commodity-exporting countries in the region recovered more quickly than the smaller commodity-importing ones. Reference [16] estimates that Latin America's improved policy environment cut the output cost of the external shocks associated with the Great Recession from the third quarter of 2008 to the second quarter of 2009 in half for Brazil, Chile, Colombia, Mexico and Peru (the financially-integrated commodity exporters), from a projected decline of 8 percent in real GDP to an actual one of about 4 percent. For the other sub-groups of countries in the region, on the other hand, which were constrained from adopting equally stimulative fiscal and monetary measures, recovery from the Great Recession was much more dependent on the external environment: the "other" commodity exporters were assisted in recovery by increases in world commodity prices, while the commodity-importing countries in the region were hampered by the slow recovery of tourism and workers' remittances. As in Asia, capital inflows also returned to Latin America rather quickly. Large nonresident portfolio outflows turned out to be short-lived, and inflows returned to the larger countries in the first part of 2009. Overall, foreign exchange reserves remained above end-2007 levels in the region.

Except for South Africa, most countries in the subSaharan African region seem to have hit bottom in the first quarter of 2009. In contrast with past crises, recovery in the region was faster than in the rest of the world, both because more policy shock absorbers such as lower interest rates were at work, and because countries in the region were able to resist harmful measures such as procyclical fiscal policies and increased trade restrictions. While growth rates averaged over 6 percent from 2003 to 2008, growth fell to 2 percent in 2009, but was already projected by the IMF to recover to 4 1/2 percent in 2010 
and to over 5 percent in 2011.

Oil importing countries in the region were hit less hard by the crisis than oil exporters, because of their limited financial links with the rest of the world as well as their limited manufactured exports. However, the crisis was acute for oil importers in the Caucasus and Central Asia, because of their close links with Russia, an oil-exporting country that suffered a sharp contraction in 2009. While several countries in the region have implemented countercyclical monetary and fiscal policies, high levels of public debt have forced them to moderate the size of their fiscal stimulus and restrict its duration. Accordingly, these countries have been particularly affected by the crisis. On the other hand, countercyclical polices helped many oil exporters in the Middle East as well as in the Caucasus and Central Asia to moderate their growth slowdowns. Kazakhstan, however, is a special case. Banks in Kazakhstan relied heavily on borrowing from foreign banks and used those funds, often in the form of short-term liabilities, for lending to unhedged domestic borrowers in construction and real estate, very much as in the Baltics. The depreciation of the domestic currency and curtailed supply of external bank loans caused Kazakhstan to suffer a severe Asian-style banking crisis from which it has not yet emerged at the time of writing.

Finally, the pattern of recovery in emerging Europe was linked both to the policy response to the crisis as well as to pre-crisis vulnerabilities, especially in the financial sector. Countries such as Hungary, Latvia and Romania had failed to build up fiscal space during the boom years to allow them to undertake countercyclical fiscal policies in response to the crisis, and their fiscal policies therefore responded procyclically, prolonging the output contraction in those countries. Financial sector distress slowed the recovery process in Estonia and Lithuania. By contrast Turkey, which was able to undertake countercyclical fiscal measures and avoided the financial sector weaknesses of the Baltic countries, was projected by the IMF to recover to growth rates of over 5 percent in 2010 and over 3 percent in 2011, after contracting by 4.7 percent in 2009 .

\section{Summary and Conclusions}

The growth payoff from the macroeconomic reforms that many emerging and developing economies undertook during the $1990 \mathrm{~s}$ has been hard to identify in the data. This has led some prominent observers to search for alternative growth strategies focusing on "second- generation" (institutional) reforms or reforms focusing on the "binding constraints" on growth, which may consist of a variety of factors other than macroeconomic instability. But the growth payoff from macroeconomic stability has often been understood as arising primarily from the improved allocation of resources and enhanced incentives for investment that can be achieved by preventing domestic macroeconomic policies from themselves destabilizing the macroeconomic environment in emerging and developing economies. To the extent that this is true, growth-promoting macroeconomic arrangements would be those that adopt strict rules to narrowly circumscribe policy discretion-e.g., "hard" exchange rate pegs and balanced-budget rules.

I have argued in this paper that this is only part of the story-that what matters for growth is not just the prevention of macroeconomic instability created by domestic policies, but also the ability to deploy domestic macroeconomic policies effectively to counter the effects of exogenous shocks. Emerging and developing countries have not been characterized by an inability to accelerate growth, but rather by an inability to sustain rapid growth in the face of large adverse shocks, and such shocks have not always been of domestic policy origin. The result has been growth instability, in the form of periods of rapid growth ended by sharp recessions that have often been followed by "lost half-decades" or even worse, "lost decades," in turn resulting in low, non-converging, average growth rates.

The purpose of macroeconomic reforms, therefore, is not just to prevent domestic macro policies from serving as a source of destabilizing shocks, but also to permit them to play an active stabilizing role in response to exogenous non-policy shocks. This role becomes more urgent as emerging and developing economies pursue growth through increased commercial and financial openness. Whether or not that strategy proves growthenhancing, it undoubtedly increases the exposure of such economies to external real and financial shocks. This creates a premium on macroeconomic arrangements that can preserve domestic stability in the face of such shocks.

What is needed, therefore, is a domestic macroeconomic policy framework that promotes not just credibility, but also flexibility. This cannot be achieved by "tying the hands" of policy makers in the areas of fiscal, monetary, exchange rate, and financial policies. Reforms of budgetary procedures to avoid pro-cyclicality, Central bank autonomy, some degree of exchange rate flexibility, and financial sector policies that promote soundness without stifling dynamism in the financial sector, are the institutional components of such a framework. Low levels of government debt, high levels of foreign exchange reserves, and high levels of confidence achieved through a track record of responsible fiscal policies and low inflation, are the "stock" components. But the key point is that these reforms are not ends in 
themselves. They are rather the means to achieve the policy flexibility required to preserve a stable growth environment in the face of exogenous shocks.

The Great Recession has provided a test of this proposition. Emerging and developing economies did not escape the effects of the recession, precisely because the outward-oriented components of their reforms in the 1990s and early 2000s increased their exposure to external shocks. But the reforms that many of those countries had previously undertaken in the macroeconomic sphere -in the forms of enhanced financial system soundness, improved budgetary processes, enhanced Central bank autonomy, more flexible exchange rate arrangements, reduced public debt and larger stocks of foreign exchange reserves, together with their low-inflation track records - made it possible for a large number of them to adopt aggressive countercyclical policies in response to the recession. This constituted a sharp break from the past, and has paid off in the form of substantial short-run growth resilience, to the point that the international recovery has been led by emerging and developing economies. It remains to be seen whether this short-run resilience translates into the long-run resilience that is required for convergence, but the lessons of past growth performance in these countries give grounds for optimism.

In short, the lesson of the Great Recession is that building macroeconomic resiliency is investing in development. Like any other type of investment, investment in macroeconomic resiliency is costly. Reducing public sector debt or accumulating foreign exchange reserves, for example, implies foregoing spending or tax cuts. Such investment can therefore undoubtedly be overdone, and it therefore remains to be determined just how much investment in macroeconomic resiliency is optimal in specific country circumstances. The key lesson from the recent past, however, is that while it can be overdone, it should not be underdone.

\section{References}

[1] J. E. Stiglitz, "More Instruments and Broader Goals: Moving toward the Post-Washington Consensus," WIDER Annual Lectures, 1998.

[2] H. Ricardo, D. Rodrik and A. Velasco, "Growth Diagnostics,” In: J. Stiglitz and N. Serra, Eds., The Washington Consensus Reconsidered: Toward a New Global Governance, Oxford University Press, New York, 2008.

[3] R. Dani, "Goodbye Washington Consensus, Hello Washington Confusion," Harvard University, Unpublished, 2006.
[4] E. William, N. Loayza and P. J. Montiel, "Has Latin America's Post-Reform Growth Been Disappointing?” Journal of International Economics, Vol. 43, No. 3-4, 1997, pp. 287-311. doi:10.1016/S0022-1996(97)00004-4

[5] E. Fernandez-Arias and P. J. Montiel, "Reform and Growth in Latin America: All Pain and No Gain?” IADB, Research Department Working Paper No. 351, August 1997.

[6] N. Loayza, P. Fajnzylber and C. Calderon, "Economic Growth in Latin America and the Caribbean: Stylized Facts, Explanations, and Forecasts," Central Bank of Chile Working Paper No. 265, 2005.

[7] P. J. Montiel, and L. Serven, "Macroeconomic Stability in Developing Countries: How Much Is Enough?” World Bank Research Observer, Vol. 21, No. 2, 2006, pp. 151178.

[8] T. Becker and P. Mauro, "Output Drops and the Shocks That Matter,” IMF Working Paper WP/06/172, 2006.

[9] P. Chuhan and F. Sturzenegger, "Default Episodes in the 1980s and 1990s: What Have We Learned?” Universidad Torcuato Di Tella, Unpublished, 2004.

[10] M. Gavin and R. Perotti, "Fiscal Policy in Latin America,” In: NBER Macroeconomics Annual, MIT Press, Cambridge, 1997.

[11] C. Reinhart and K. S. Rogoff, "The Modern History of Exchange Rate Arrangements: A Reinterpretation," Quarterly Journal of Economics, Vol. 119, No. 1, 2002, pp. 1-48

[12] L. Pritchett, "Understanding Patterns of Economic Growth: Searching for Hills among Plateaus, Mountains, and Plains,” World Bank Economic Review, 2000.

[13] P. Osterholm and J. Zettelmeyer, "The Effects of External Conditions on Growth in Latin America,” IMF Working Paper WP/07/176, 2007.

[14] L. Hernandez and P. J. Montiel, "Post-Crisis Exchange Rate Policy in Five Asian Countries: Filling in the 'Hollow Middle'?” IMF Working Paper WP/01/170, 2003.

[15] International Monetary Fund, "Regional Economic Outlook: Asia and the Pacific,” October 2009.

[16] International Monetary Fund, "Regional Economic Outlook: Western Hemisphere,” April 2009.

[17] J. Aizenman and G. K. Pasricha, "Net Fiscal Stimulus during the Great Recession,” NBER Working Paper 16779, 2011.

[18] International Monetary Fund, "Regional Economic Outlook: Sub-Saharan Africa,” October 2009.

[19] International Monetary Fund, "Regional Economic Outlook: Sub-Saharan Africa,” April 2010.

[20] International Monetary Fund, "Regional Economic Outlook: Middle East and Central Asia,” October 2009.

[21] International Monetary Fund, "Regional Economic Outlook: Asia and the Pacific,” April 2010. 